\title{
Pengaruh Transparansi dan Akuntabilitas Terhadap Kinerja Instansi Pemerintah
}

\author{
Ait Novatiani ${ }^{1}$, R. Wedi Rusmawan Kusumah ${ }^{2}$, Diandra Pepi Vabiani ${ }^{3}$ \\ Sekolah Pascasarjana, Universitas Widyatama, Bandung, Indonesia ${ }^{1 \& 2}$ \\ Program Studi Akuntansi, Universitas Widyatama, Bandung, Indonesia ${ }^{3}$
}

\begin{abstract}
This study aims to determine transparency and accountability in West Bandung Regency SKPD and the influence of transparency and accountability on the performance of government agencies in West Bandung Regency SKPD both partially and simultaneously. The type of research used is explanatory. The population in this study were 27 Regional Work Unit (SKPD) in West Bandung Regency. Hypothesis testing was tested using $t$ test and F test. Based on the results of the study showed that transparency and accountability in SKPD West Bandung Regency was good, the results of hypothesis testing showed that transparency and accountability affect the performance of government agencies both partially and simultaneously.
\end{abstract}

Keywords: Transparency, Accountability and Performance of Government Agencies.

Abstrak. Penelitian ini bertujuan untuk mengetahui transparansi dan akuntabilitas di SKPD Kabupaten Bandung Barat serta pengaruh transparansi dan akuntabilitas terhadap kinerja instansi pemerintah pada SKPD Kabupaten Bandung Barat baik secara parsial maupun secara simultan. Jenis penelitian yang digunakan adalah explanatory. Populasi dalam penelitian ini adalah 27 Satuan Perangkat Kerja Daerah (SKPD) di Kabupaten Bandung Barat. Pengujian hipotesis diuji dengan menggunakan uji t dan uji F. Berdasarkan hasil penelitian menunjukan bahwa transparansi dan akuntabilitas di SKPD Kabupaten Bandung Barat sudah baik, hasil pengujian hipotesis menunjukkan bahwa transparansi dan akuntabilitas berpengaruh terhadap kinerja instansi pemerintah baik secara parsial maupun secara simultan.

Kata kunci : Transparansi, Akuntabilitas dan Kinerja Instansi Pemerintah

Correspondence. Email : ait.novatiani@widyatama.ac.id

History of article. Received: Oktober 2018, Revision: Januari 2019, Published: Maret 2019

\section{PENDAHULUAN}

Dalam organisasi sektor publik, kinerja instansi pemerintah merupakan gambaran mengenai tingkat pencapaian sasaran ataupun tujuan instansi pemerintah sebagai penjabaran dari visi, misi dan strategi instansi pemerintah yang mengindikasikan tingkat keberhasilan dan kegagalan pelaksanaan kegiatan-kegiatan sesuai dengan program dan kebijakan yang ditetapkan (PP No. 24 Tahun 2005). Tuntutan akan kinerja yang baik ini terjadi hampir di semua pemerintahan seiring dengan konsep otonomi daerah dan penetapan peraturan perundangundangan terkait pengelolaan pemerintahan (Bharata, 2015).

Kinerja dapat terlihat dari pelaksanaan pembangunannya. Pelaksanaan pembangunan harus mengarah kepada penciptaan good governance yang diterjemahkan sebagai "Tata Kelola Pemerintahan yang Baik". Timbulnya konsep good governance karena adanya ketidakpuasan pada kinerja pemerintahan yang selama ini dipercaya sebagai penyelenggara urusan publik (Ibrahim, 2015).

Permasalahan yang berhubungan dengan kinerja pemerintah daerah adalah buruknya kinerja pelayanan publik. Keluhan masyarakat beberapa tahun terakhir yang berkaitan dengan penyimpangan penyelenggaraan pelayanan publik yang menduduki peringkat pertama masih keluhan mengenai kinerja pemerintah daerah. Berdasarkan data yang diterima dari Ombudsman RI periode 1 Januari 2016 - 8 Januari 2017, ada 10.158 aduan yang diterima, 1.200 di antaranya laporan tembusan dari instansi yang diadukan pelayanannya. Berikut ini data aduan warga yang diterima Ombudsman RI selama tahun 2016: 
Tabel 1. Data Aduan Pelayanan Publik

\begin{tabular}{clc}
\hline NO & \multicolumn{1}{c}{ ASPEK } & JUMLAH \\
\hline 1 & Badan Pertahanan Nasional & 693 \\
2 & BUMN/BUMD & 715 \\
3 & Dewan Perwakilan Rakyat & 25 \\
4 & Kementerian & 685 \\
5 & Kejaksaan & 143 \\
6 & Kepolisian & 1.833 \\
7 & Komisi Negara/Lembaga Negara Non & 93 \\
8 & Struktural & 542 \\
9 & Lain-lain & 46 \\
10 & Kembaga Pemerintah Non & 295 \\
11 & Lembaga Pendidikan Negeri & 428 \\
12 & Pemerintah Daerah & 4.117 \\
13 & Perbankan & 181 \\
14 & Perguruan Tinggi Negeri & 113 \\
15 & Rumah Sakit Pemerintah & 210 \\
16 & Tentara Nasional Indonesia & 39 \\
\hline & $\quad$ Sumber: Ombudsman RI
\end{tabular}

Dari data tabel di atas, Ombudsman RI melakukan tabulasi pada 16 jenis instansi. Dari 16 instansi tersebut, terlihat 5 instansi yang paling banyak diadukan adalah instansi Pemda sebanyak 4.117 aduan, disusul Kepolisian 1.833 aduan, BUMN/BUMD 715 aduan, Badan Pertanahan Nasional (BPN) 693 aduan, dan kementerian 6.854 aduan. Tercatat oleh Ombudsman Republik Indonesia, aduan yang diterima mengalami peningkatan. Pada 2016, Ombudsman RI menerima 10.158 laporan masyarakat. Jumlah itu meningkat 48,2 \% dibandingkan 2015 yang terdapat 6.854 aduan. Hal ini menunjukkan bahwa kinerja instansi pemerintah Indonesia masih kurang memuaskan bagi masyarakat Indonesia.

Kinerja pemerintah harus diukur agar diketahui bagaimana pemerintah melaksanakan apa yang menjadi tanggung jawabnya. Pengukuran kinerja merupakan suatu proses sistematis untuk menilai apakah program kegiatan yang telah direncanakan telah dilaksanakan sesuai dengan rencana tersebut, dan yang lebih penting adalah apakah telah mencapai keberhasilan yang telah ditargetkan pada saat perencanaan. Pengukuran kinerja dimulai dengan penetapan indikator kinerja yang memberikan informasi sedemikian rupa sehingga memungkinkan unit kerja sektor publik untuk memonitor kinerjanya dalam menghasilkan output dan outcome terhadap masyarakat. Dalam hal indikator kinerja, sebagai dasar untuk mengukur kinerja, dipakai indikator input, output, outcome, benefit dan impact. Pengukuran kinerja bermanfaat untuk membantu para pengambil keputusan untuk memonitor dan memperbaiki kinerja yang berfokus pada tujuan organisasi dalam rangka memenuhi ketentuan akuntabilitas publik (Nordiawan \& Hertianti, 2010).

Menurut penilaian Kementerian Pendayagunaan Aparatur Negara dan Reformasi Birokrasi (KemenPAN RB), rata-rata nilai kinerja pemerintah daerah masih $\mathrm{C}$ alias masih kurang. MenPAN RB Asman Abnur menyatakan, berdasar hasil evaluasi Akuntabilitas Kinerja Instansi Pemerintah (AKIP), rata-rata nilai pemerintah kabupaten dan kota seluruh Indonesia pada 2016 hanya 49,87 (www.beritagar.id). Salah satu kabupaten yang mendapat nilai kinerja $\mathrm{C}$ adalah Kabupaten Bandung Barat. Hasil penilaian tersebut merupakan salah satu indikator baik buruknya kinerja pegawai dalam menjalankan tugasnya sebagai abdi negara. Direktur Pusat Kajian Politik Ekonomi dan Pembangunan (Puskapol Ekbang) Kabupaten Bandung Barat (KBB), Holid Nurjamil menilai bahwa perencanaan strategis dan perencanaan kinerja di KBB tidak sinergis dan tidak berarah dengan RPJMD (Rencana Pembangunan Jangka Menengah Daerah). Selain perencanaan, aspek capaian indikator kinerja pun dinilai banyak yang tidak mencapai target. Pencapaian indikator kinerja merupakan perwujudan transparansi dan akuntabilitas penyelenggaraan pemerintahan dan pembangunan daerah. (www.pasundanekspres.com).

Pemerintah Kabupaten Bandung Barat menjadi sorotan publik seiring dengan proses pembangunan yang dilakukan karena mendapat opini Wajar Dengan Pengecualian (WDP) atas Laporan Keuangan Pemerintah Daerah (LKPD) Tahun 2016 dari Badan Pemeriksa Keuangan. Ini kelima kalinya Pemkab Bandung Barat mendapatkan opini WDP. Opini BPK ini 
merupakan salah satu ukuran kinerja dalam bidang pengelolaan keuangan, sehingga dapat dikatakan kinerja keuangan SKPD Kabupaten Bandung Barat masih perlu perbaikan (www.pikiran-rakyat.com).

Adapun hasil pencapaian Kinerja Badan Kepegawaian dan Pengembangan Sumber Daya Manusia Kabupaten Bandung Barat Tahun 2016 tersaji pada tabel berikut:

Tabel 2. Capaian Indikator Kinerja Utama Badan Kepegawaian dan Pengembangan Sumber Daya Manusia Kabupaten Bandung Barat Tahun 2016

\begin{tabular}{|c|c|c|c|c|}
\hline \multirow[b]{2}{*}{ No } & \multirow[b]{2}{*}{ Indikator } & \multicolumn{3}{|c|}{ Kinerja } \\
\hline & & Target & Realisasi & (\%) \\
\hline 1 & $\begin{array}{l}\text { Persentase SKPD } \\
\text { yang tidak terdapat } \\
\text { Pelanggaran Disiplin }\end{array}$ & 93 & 86,36 & 92,90 \\
\hline 2 & $\begin{array}{lr}\text { Persentase } & \\
\text { Kenaikan Pangkat } \\
\text { Pegawai } \\
\text { Waktu }\end{array}$ & 92 & 90,91 & 98,82 \\
\hline
\end{tabular}

Sumber :www.eporja.bandungbaratkab.go.id

Berdasarkan tabel tersebut terlihat bahwa terdapat 2 indikator tidak mencapai target yaitu indikator kinerja utama Persentase SKPD yang tidak terdapat Pelanggaran Disiplin sebesar 92,90\% karena realisasinya dibawah target yaitu 86,36\%. Adapun Persentase Kenaikan Pangkat Pegawai Tepat Waktu sebesar $98,82 \%$ dengan realisasi sebesar 90,91\%.

Adapun hasil pencapaian Kinerja Badan Kepegawaian dan Pengembangan Sumber Daya Manusia Kabupaten Bandung Barat Tahun 2016 tersaji pada tabel berikut:

Tabel 3. Capaian Indikator Kinerja Utama Dinas Kesehatan Kabupaten Bandung Barat Tahun 2016

\begin{tabular}{|c|c|c|c|c|c|}
\hline \multirow{2}{*}{ No } & \multirow{2}{*}{\multicolumn{2}{|c|}{ Indikator }} & \multicolumn{3}{|c|}{ Kinerja } \\
\hline & & & Target & Realisasi & (\%) \\
\hline 1 & $\begin{array}{l}\text { Angka } \\
\text { Harapan } \\
(\mathrm{AHH})\end{array}$ & $\begin{array}{l}\text { Usia } \\
\text { Hidup }\end{array}$ & 69,81 & 69,37 & 99,37 \\
\hline 2 & $\begin{array}{l}\text { Persentase } \\
\text { Puskesmas } \\
\text { Terakreditasi }\end{array}$ & yang & 15 & 14,4 & 99 \\
\hline
\end{tabular}

Sumber :www.eporja.bandungbaratkab.go.id

Berdasarkan tabel tersebut terlihat bahwa terdapat 2 indikator tidak mencapai target yaitu indikator kinerja utama Angka Usia Harapan Hidup (AHH) sebesar 99,37\% karena realisasinya dibawah target yaitu $69,37 \%$. Persentase Puskesmas yang Terakreditasi sebesar $99 \%$ dengan realisasi sebesar $14,4 \%$.

Atas fenomena tersebut maka untuk mencapai kinerja instansi pemerintah yang baik, pemerintah daerah dalam proses pembangunannya harus mengarah kepada penciptaan transparansi dan akuntabilitas. Adanya penerapan transparansi dan akuntabilitas, tujuan penting instansi pemerintah dalam memberikan pelayanan publik melalui kinerjanya dapat diukur dan di pertanggungjawabkan (Lukito, 2014).

Transparansi adalah memberikan informasi yang terbuka dan jujur kepada masyarakat berdasarkan pertimbangan bahwa masyarakat memiliki hak untuk mengetahui secara terbuka dan menyeluruh atas pertanggungjawaban pemerintah dalam pengelolaan sumber daya yang dipercayakan kepadanya dan ketaatannya pada peraturan perundang- undangan. (Peraturan Pemerintah Nomor 71, 2010). Adanya transparansi dalam penyelenggaraan pemerintahan daerah, terjadi peningkatan terhadap kinerja karena semua kegiatan, program, pengelolaan keuangan dilakukan dengan terbuka dan dipublikasikan ke masyarakat (Saputra, Darwanis \& Abdullah, 2014). Dengan memperluas saluran transparansi yang ada selama ini di pemerintahan maka pengawasan akan lebih baik dari pemberi amanah dan masyarakat sehingga tingkat pencapaian kinerja pemerintah dapat lebih baik (Auditya, dkk, 2013).

Adanya penerapan transparansi pada setiap perangkat daerah bisa meningkatkan kinerja pemerintah dengan baik dengan melakukannya keterbukaan informasi yang relevan maupun akurat. Kota Bandung klaim menjadi pemerintahan transparan dengan membahas Open Government Indonesia (OGI). Pemerintahan yang transparan dapat meningkatkan kepercayaan masyarakat terhadap kinerja pemerintah. Dikatakan transparan apabila dalam penyelenggaraan pemerintahannya mudah diakses atau diketahui oleh masyarakat sehingga masyarakat bisa memantau sekaligus mengevaluasi kinerja 
pemerintah. Langkah yang diambil untuk OGI adalah dengan melanjutkan upaya untuk membangun pemerintahan yang lebih terbuka, partisipatif, dan inovatif sehingga dalam kinerja pemerintah diharapkan meningkat. (www.pikiran-rakyat.com)

Akuntabilitas merupakan perwujudan kewajiban seseorang atau unit organisasi untuk mempertanggungjawabkan pengelolaan dan pengendalian sumber daya dan pelaksanaan kebijakan yang dipercayakan kepadanya dalam rangka pencapaian tujuan. Kesadaran akuntabilitas pada seorang pegawai akan berpengaruh dalam melakukan pekerjaannya dan tugas-tugasnya dengan sebaik-baiknya. Akuntabiltas juga menitikberatkan pada peranan pengawas dan mengharapkan agar jabatan dan pegawai menetapkan suatu proses perencanaan dan penganggaran, sehingga memungkinkan mereka memberikan pelayanan publik yang terbaik dan meningkatkan kualitas kinerja. (LAN dan BPKP, 2000). Adanya

akuntabilitas publik, pemerintah daerah bisa memberikan pertanggungjawaban atas semua kegiatan yang dilaksanakan sehingga kinerja pemerintah daerah dapat dinilai baik oleh pihak internal, maupun pihak eksternal. Hal ini menegaskan pentingnya akuntabilitas publik dalam peningkatan kinerja SKPD (Saputra, Darwanis \& Abdullah, 2014). Dengan menjalankan asas akuntabilitas sebagai kewajiban pihak pemegang amanah untuk memberikan pertanggungjawaban, menyajikan, melaporkan dan mengungkapkan (disclosure) segala aktivitas dan kegiatan yang menjadi tanggung jawabnya kepada pihak pemberi amanah yang memiliki hak dan kewenangan untuk meminta pertanggungjawaban tersebut maka kualitas kinerja pemerintah daerah baik dari sisi financial dapat meningkat dan menjadi lebih baik guna mendorong terwujudnya good governance (Auditya, dkk, 2013).

Kesadaran akan pentingnya akuntabilitas diterapkan oleh Pemerintah Kota Bandung, sehingga kinerjanya meningkat. Hal ini terbukti karena Pemerintah Kota Bandung mendapat predikat $A$ atas Sistem Akuntabilitas Kinerja Instansi Pemerintah (SAKIP). Kota Bandung memperoleh nilai $A$ karena ada keterpaduan antara rencana kota secara keseluruhan dengan masing-masing SKPD yang didukung dengan ukuran kinerjanya. (www.news.okezone.com)

Berdasarkan penelitian yang telah dilakukan sebelumnya menunjukkan hasil yang berbeda-beda. Menurut (Bharata, 2015) dan (Saputra, Darwanis \& Abdullah, 2014) menyatakan bahwa akuntabilitas dan transparansi berpengaruh terhadap kinerja, sedangkan (Ibrahim, 2015) menyatakan bahwa transparansi dan akuntabilitas tidak berpengaruh terhadap kinerja instansi pemerintah.

Atas dasar uraian di atas maka peneliti tertarik melakukan penelitian dengan judul:
"PENGARUH
TRANSPARANS
DAN

AKUNTABILITAS TERHADAP KINERJA INSTANSI PEMERINTAH (Survey Pada SKPD di Kabupaten Bandung Barat)".

Tujuan penenlitian ini adalah untmengetahui transparansi dan akuntabilitas di SKPD Kabupaten Bandung Barat, pengaruh transparansi dan akuntabilitas terhadap kinerja instansi pemerintah pada SKPD Kabupaten Bandung Barat baik secara parsial maupun secara simultan.

\section{KERANGKA PENELITIAN \& HIPOTESIS}

\section{Transparansi}

Menurut Mardiasmo (2009) , pengertian transparansi adalah sebagai berikut:

"Transparansi berati keterbukaan (openness) pemerintah dalam memberikan informasi yang terkait dengan aktivitas pengelolaan sumber daya publik kepada pihak-pihak yang membutuhkan informasi."

\section{Prinsip dan indikator Transparansi}

Menurut Krina (2003), prinsip-prinsip transparansi menekankan pada dua aspek dengan indikator-indikator : Komunikasi publik oleh pemerintah yaitu meliputi :penyediaan informasi yang jelas tentang tanggung jawab dan menyusun suatu mekanisme pengaduan jika ada peraturan yang ssepidilanggar atau permintaan untuk membayar uang suap. Hak masyarakat terhadap akses informasi 
yaitu meliputi : Kemudahan akses informasi dan

meningkatkan arus informasi melalui

kerjasama dengan media massa išpe idan

lembaga non pemerintah.

\section{Akuntabilitas}

Menurut Mardiasmo (2009),

menjelaskan bahwa pengertian akuntabilitas adalah sebagai berikut:

"Kewajiban pemegang amanah (agent) untuk memberikan pertanggungjawaban, menyajikan, melaporkan, dan mengungkapkan segala aktivitas dan kegiatan yang menjadi tanggung jawabnya kepada pihak pemberi amanah (principle) yang memiliki hak dan kewenangan untuk meminta pertanggung-jawaban tersebut."

\section{Dimensi Akuntabilitas}

Menurut Mardiasmo (2009) yang mengutip dari Elwood (1993), Akuntabilitas yang harus dilakukan oleh organisasi sektor publik terdiri atas beberapa dimensi dan indikatornya : akuntabilitas Kejujuran dan Hukum yaitu meliputi: penghindaran korupsi dan kolusi dan kepatuhan terhadap hukum. Akuntabilitas Proses yang meliputi : adanya kepatuhan terhadap prosedur. adanya pelayanan publik yang cepat, adanya pelayanan publik yang responsive dan adanya pelayanan publik yang murah biaya. Akuntabilitas program yang meliputi : mempertanggung jawabkan yang telah dibuat dan ogram yang sesuai dengan tujuan hasil yang optimal. Akuntabilitas Kebijakan yaitu empertanggungjawabkan kebijakan yang telah diambil.

\section{Indikator Kinerja Instansi Pemerintah}

Indikator kinerja merupakan informasi yang dapat digunakan untuk mengukur status pencapaian kinerja suatu program/kegiatan terhadap sasaran yang sudah direncanakan. Dalam modul SAKIP (LAN \& BPKP, 2004) terdapat beberapa indikator kinerja yang sering digunakan dalam pelaksanaan pengukuran kinerja organisasi, yaitu: indikator masukan (input), indikator proses (process), indikator keluaran (output), indikator hasil (outcome), indikator manfaat (benefit), dan indikator dampak (impact). Indikator masukan (input) adalah segala sesuatu yang dibutuhkan agar pelaksanaan kegiatannya dapat berjalan untuk menghasilkan keluaran, indikator ini dapat berupa dana, sumber daya manusia, informasi, kebijakan, atau peraturan perundang-undangan, dan sebagainya. is iveplindikator proses (process) adalah segala besaran yang menunjukkan upaya yang dilakukan dalam rangka mengolah masukan menjadi keluaran. Indikator proses menggambarkan perkembangan atau aktivitas yang terjadi atau dilakukan selama pelaksanaan kegiatan berlangsung khususnya dalam proses mengolah masukan menjadi keluaran. išpi Indikator keluaran (output) adalah segala sesuatu yang diharapkan langsung dicapai dari suatu kegiatan yang dapat berupa fisik ataupun non fisik. Dengan membandingkan keluaran dari instansi dapat dianalisis apakah suatu kegiatan terlaksana sesuai dengan rencana. Indikator hasil (outcome) adalah segala sesuatu yang terkait dengan tujuan akhir dari pelaksanaan kegiatan. istepilndikator ini menggambarkan hasil nyata dari keluaran suatu kegiatan. Konsep outcome lebih sulit dibandingkan input dan output. Outcome mengukur apa yang telah di capai. Dengan kata lain outcome adalah hasil yang di capai dalam suatu program atau aktifitas dibandingkan dengan hasil yang diharapkan. Hasil yang diharapkan bisa berupa target kinerja yang di harapkan, sedangkan outcome adalah hasil nyata yang dicapai. istep Indikator manfaat (benefit) menggambarkan manfaat yang diperoleh dari indikator hasil. Manfaat tersebut baru tampak setelah beberapa waktu kemudian, khususnya dalam jangka menengah dan jangka panjang. Indikator manfaat menunjukan hal yang diharapkan untuk dicapai bila keluaran dapat diselesaikan dan berfungsi dengan optimal (tepat lokasi dan waktu). Indikator dampak (impact) adalah pengaruh yang ditimbulkan baik positif maupun negatif pada setiap tingkatan indikator berdasarkan asumsi yang telah ditetapkan. Indikator ini sulit diukur karena memerlukan waktu lebih dari satu periode untuk mengetahui dampaknya.

3. METODE PENELITIAN 
Metode penelitian yang digunakan dalam penelitian ini adalah penelitian eksplanatori. Menurut Sugiyono (2012), penelitian eksplanatori (explanatory research) adalah penelitian yang bermaksud menjelaskan kedudukan variabel-variabel yang diteliti serta hubungan antara variabel yang satu dengan yang lain.

\section{Populasi dan Sampel Penelitian}

Populasi penelitian ini adalah 27 SKPD pada Kabupaten Bandung Barat. Responden dalam penelitian ini adalah seluruh pegawai yang ada pada 27 SKPD Kabupaten Bandung Barat.

Berikut adalah daftar Satuan Kerja Perangkat Daerah di lingkungan pemerintah Kabupaten Bandung:

Tabel 4. Daftar Perangkat Daerah Pemerintah Kabupaten Bandung Barat

\begin{tabular}{|c|c|}
\hline No & SKPD \\
\hline 1 & Inspektorat Daerah \\
\hline 2 & Sekretariat DPRD \\
\hline \multicolumn{2}{|c|}{ Dinas } \\
\hline 3 & Dinas Kearsipan dan Perpustakaan \\
\hline 4 & Dinas Kepemudaan dan Olahraga \\
\hline 5 & Dinas Kependudukan dan Pencatatan Sipil \\
\hline 6 & Dinas Kesehatan \\
\hline 7 & Dinas Komunikasi, Informatika dan Statistik \\
\hline 8 & Dinas Koperasi, Usaha Kecil dan Menengah \\
\hline 9 & Dinas Lingkungan Hidup \\
\hline 10 & Dinas Pariwisata dan Kebudayaan \\
\hline 11 & Dinas Pekerjaan Umum dan Penataan Ruang \\
\hline 12 & Dinas Pemberdayaan Masyarakat Desa \\
\hline 13 & $\begin{array}{l}\text { Dinas Penanaman Modal dan Pelayanan Terpadu } \\
\text { Satu Pintu }\end{array}$ \\
\hline 14 & Dinas Pendidikan \\
\hline 15 & $\begin{array}{l}\text { Dinas Pengandalian Penduduk, Keluarga } \\
\text { Berencana, Pemberdayaan Perempuan dan } \\
\text { Perlindungan Anak }\end{array}$ \\
\hline 16 & Dinas Perhubungan Komunikasi dan Informatika \\
\hline 17 & Dinas Perikanan dan Peternakan \\
\hline 18 & Dinas Perindustrian Perdagangan \\
\hline 19 & Dinas Pertanian dan Ketahanan Pangan \\
\hline 20 & Dinas Perumahan dan Pemukiman \\
\hline 21 & Dinas Sosial \\
\hline 22 & Dinas Tenaga Kerja dan Transmigrasi \\
\hline 23 & $\begin{array}{l}\text { Badan Kepegawaian dan Pengembangan Sumber } \\
\text { Daya Manusia }\end{array}$ \\
\hline \multicolumn{2}{|c|}{ Badan } \\
\hline 24 & Badan Pengelolaan Keuangan Daerah \\
\hline 25 & $\begin{array}{l}\text { Badan Perencanaan Pembangunan, Penelitian dan } \\
\text { Pengembangan Daerah }\end{array}$ \\
\hline 26 & Kantor Kesatuan Bangsa dan Politik \\
\hline
\end{tabular}

\begin{tabular}{|c|c|}
\hline No & SKPD \\
\hline \multirow{2}{*}{\multicolumn{2}{|c|}{27}} \\
\hline & \\
\hline \multicolumn{2}{|r|}{$\begin{array}{l}\text { Sumber: Struktur Organisasi Tata Kerja } \text { (SOTK } \\
\text { Pemerintah Kab. Bandung Barat }\end{array}$} \\
\hline $\begin{array}{l}\text { meng } \\
\text { dalan } \\
\text { Kepal } \\
\text { Band } \\
\text { selam } \\
\text { dipan }\end{array}$ & $\begin{array}{l}\text { Teknik pengambilan sampel dengan } \\
\text { ggunakan teknik purposive sampling. Sampel } \\
\text { n penelitian ini adalah Kepala Dinas, Sekretaris, } \\
\text { la Sub Bagian dari } 27 \text { SKPD di Kabupaten } \\
\text { ung Barat yang memiliki pengalaman kerja } \\
\text { ha } 1 \text { (satu) tahun atau lebih pada SKPD karena } \\
\text { dang telah memiliki pemahaman terhadap } \\
\text { si dan kondisi yang ada di dalam SKPD yaitu }\end{array}$ \\
\hline
\end{tabular}

\section{Teknik Pengumpulan Data}

Teknik pengumpulan data yang digunakan adalah: data primer, dengan cara : kuesioner dan data sekunder, dengan cara : studi kepustakaan (library research)

\section{HASIL DAN PEMBAHASAN}

Transparansi pada SKPD Kabupaten Bandung Barat

Berdasarkan hasil penelitian bahwa transparasi di SKPD Kabupaten Bandung Barat sudah baik, karena telah menerapkan prinsipprinsip transparansi yaitu adanya komunikasi publik oleh pemerintah dan hak masyarakat terhadap akses informasi. Hal ini sesuai dengan teori yang dikemukakan oleh Krina (2003). Dari hasil kuisioner diperoleh skor rata-rata sebesar 3,62 yang berada pada rentang interval 3,40 4,20 dalam kategori baik. Tetapi dari hasil kuisioner komunikasi publik oleh pemerintah mengenai adanya mekanisme / pelayanan pengaduan jika terjadi pelanggaran atau permintaan untuk membayar uang suap diperoleh nilai yang tinggi untuk jawaban tidak setuju sebanyak 12 orang. Hal ini mengindikasikan bahwa di SKPD Kabupaten Bandung Barat masih belum adanya mekanisme / pelayanan pengaduan jika terjadi pelanggaran atau permintaan untuk membayar uang suap. Tetapi secara keseluruhan untuk komunikasi publik oleh pemerintah di SKPD Kabupaten Bandung Barat dalam kategori baik, karena 
diperoleh skor sebesar 3,68, dimana 3,68 berada pada interval 3,40-4,20 dalam kategori baik.

\section{Akuntabilitas pada SKPD Kabupaten Bandung Barat}

Berdasarkan hasil penelitian bahwa akuntabilitas di SKPD Kabupaten Bandung Barat sudah baik, karena sudah memenuhi kriteria 4 (empat) dimensi yaitu akuntabilitas hukum dan kejujuran, akuntabilitas proses, akuntabilitas program dan akuntabilitas kebijakan. Hal ini sesuai dengan teori yang dikemukakan oleh Mardiasmo (2009). Hasil kuisioner diperoleh skor rata-rata sebesar 3,83 yang termasuk kategori baik karena berada pada interval 3,40 - 4,20. Tetapi dari hasil kuisioner akuntabilitas proses mengenai adanya pelayanan publik yang responsif diperoleh nilai yang tinggi untuk jawaban tidak setuju sebanyak 7 orang. Hal ini mengindikasikan bahwa di SKPD Kabupaten Bandung Barat masih belum adanya pelayanan publik yang responsif. Tetapi secara keseluruhan untuk akuntabilitas proses di SKPD Kabupaten Bandung Barat dalam kategori baik, karena diperoleh skor sebesar 3,74, dimana 3,74 berada pada interval $3,40-4,20$ dalam kategori baik.

\section{Kinerja Instansi Pemerintah pada SKPD Kabupaten Bandung Barat}

Berdasarkan hasil penelitian bahwa kinerja instansi pemerintah pada SKPD Kabupaten Bandung Barat sudah baik karena sudah memenuhi indikator-indikator kinerja instansi pemerintah yaitu adanya masukan (input), proses (process),keluaran (output), hasil (outcome), manfaat (benefit) dan dampak (impact). Hal ini sesuai dengan teori yang dikemukakan oleh Lembaga Administrasi Negara dan Badan Pengawasan Keuangan dan Pembangunan (2004). Disamping itu dari kuesioner diperoleh sebesar 3,61 dalam kategori baik karena berada pada rentang interval 3,40 4.20. Tetapi dari hasil kuisioner hasil (outcome) mengenai aktivitas pencapaian suatu program dibandingkan dengan target kinerja diperoleh nilai yang tinggi untuk jawaban tidak setuju sebanyak 14 orang. Hal ini mengindikasikan bahwa di SKPD Kabupaten Bandung Barat masih belum adanya aktivitas pencapaian suatu program dibandingkan dengan target kinerja.
Tetapi secara keseluruhan untuk akuntabilitas proses di SKPD Kabupaten Bandung Barat dalam kategori baik, karena diperoleh skor sebesar 3,55, dimana 3,55 berada pada interval 3,40 4,20 dalam kategori baik.

\section{Pengaruh Transparansi terhadap Kinerja Instansi Pemerintah}

Berdasarkan hasil uji $\mathrm{t}$ menunjukkan bahwa transparansi berpengaruh terhadap kinerja instansi pemerintah, hal ini ditunjukkan dengan nilai $t_{\text {hitung }}$ diperoleh sebesar 2,432. Dimana $t_{\text {hitung }}$ lebih besar dari $t_{\text {tabel }}$ yaitu $t_{\text {hitung }}$ 2,432. $>t_{\text {tabel }} 1,991$. Adapun dari hasil perhitungan koefisien determinasi parsial menunjukkan bahwa transparansi $\left(X_{1}\right)$ memberikan kontribusi sebesar $10 \%$. Hal ini menunjukkan jika transparansi berjalan dengan baik maka akan meningkatkan kinerja instansi pemerintah.

Penelitian ini sejalan dengan penelitian yang dilakukan oleh Laurence, dkk (2015) dan Saputra, dkk (2014) yang menyatakan bahwa transparansi berpengaruh signifikan terhadap kinerja instansi pemerintah.

Penelitian ini juga sejalan dengan teori yang diungkapkan Mardiasmo (2009) yang menyatakan bahwa transparansi adalah keterbukaan (openness) pemerintah dalam memberikan informasi yang terkait dengan aktivitas pengelolaan sumber daya publik kepada pihak-pihak yang membutuhkan informasi.

Bila aparatur pemerintah menerapkan transparansi maka akan menampilkan kinerja terbaiknya dalam menjalankan tugas dan tanggungjawabnya. Pengawasan dan penilaian publik akan menjadi tekanan bagi aparatur pemerintah dalam bekerja sehingga akan memperlihatkan kinerjanya dengan bekerja sebaik-baiknya (Auditya, Husaini dan Lismawati, 2013). Dengan kata lain semakin tinggi transparansi pada aparatur pemerintah maka akan semakin baik pula kinerja instansi pemerintah.

\section{Pengaruh Akuntabilitas terhadap Kinerja Instansi Pemerintah}

Berdasarkan hasil pengolahan data menunjukkan bahwa akuntabilitas berpengaruh terhadap kinerja instansi pemerintah, dimana 
nilai $t_{\text {hitung }}$ diperoleh sebesar 9,965. Dimana $t_{\text {hitung }}$ lebih besar dari $t_{\text {tabel }}$ yaitu $t_{\text {hitung }} 9,965$. $>t_{\text {tabel }}$ 1,991 .

Adapun hasil perhitungan koefisien determinasi menunjukkan bahwa akuntabilitas $\left(\mathrm{X}_{2}\right)$ memberikan kontribusi paling dominan terhadap kinerja instansi (Y) dengan kontribusi yang diberikan sebesar 59,9 \%. Hal ini menunjukkan jika akuntabilitas berjalan dengan baik maka akan meningkatkan kinerja instansi pemerintah.

Penelitian ini sesuai dengan yang dikemukakan Lukito (2014) yaitu akuntabilitas merupakan bentuk kewajiban penyelenggara kegiatan publik untuk dapat menjelaskan dan menjawab segala hal menyangkut langkah dari seluruh keputusan dan proses yang dilakukan, serta pertanggungjawaban terhadap hasil dan kinerjanya.

Penelitian ini sejalan dengan penelitian yang dilakukan oleh Laurence, dkk (2015), Bharata (2015) dan Saputra, dkk (2014) yang menyatakan bahwa akuntabilitas berpengaruh signifikan terhadap kinerja instansi pemerintah.

Penelitian ini juga sejalan dengan teori yang diungkapkan Lembaga Administrasi Negara (1999) bahwa akuntabilitas adalah kewajiban untuk memberikan pertanggungjawaban dan menerangkan kinerja dan tindakan seseorang/badan hukum/pimpinan kolektif suatu organisasi kepada pihak yang memiliki hak. Akuntabilitas adalah amanat peraturan perundang-undangan yang harus dilaksanakan, dan terdapat penilaian terhadap pertanggungjawaban tersebut yang dilakukan oleh publik dan institusi pengawasan yang mempunyai konsekuensi hukum, maka aparatur pelaksana pemerintahan akan berupaya menerapkan konsep akuntabilitas sebaik mungkin. Implementasi akuntabilitas diyakini akan mampu meningkatkan kinerja organisasi pemerintahan (Auditya, Husaini dan Lismawati, 2013). Dengan kata lain semakin tinggi akuntabilitas pada aparatur pemerintah maka akan semakin baik pula kinerja instansi pemerintah.

Pengaruh Transparansi dan Akuntabilitas terhadap Kinerja Instansi Pemerintah
Berdasarkan hasil pengolahan data menunjukkan bahwa transparansi dan akuntabilitas berpengaruh terhadap kinerja instansi pemerintah, dimana nilai $F_{\text {hitung }}$ diperoleh sebesar 90,526. Dimana $F_{\text {hitung }}$ lebih besar dari $t_{\text {tabel }}$ yaitu $t_{\text {hitung }} 90,526$. $>F_{\text {tabel }} 3,114$. Koefisien determinasi simultan yang diperoleh sebesar $69,9 \%$. Hal ini menunjukan bahwa kedua variabel bebas yang diuji yang terdiri dari transparansi dan akuntabilitas memberikan kontribusi terhadap kinerja instansi Pemerintah pada SKPD di Kabupaten Bandung Barat sebesar 69,9\%. sedangkan 30,1\% lainnya merupakan kontribusi dari variabel lain yang tidak diteliti.

Penelitian ini didukung oleh penelitian sebelumnya yang dilakukan oleh Saputra, Darwanis dan Syukriy Abdullah (2015) menyimpulkan bahwa transparansi dan akuntabilitas baik secara parsial maupun simultan berpengaruh positif terhadap kinerja satuan perangkat daerah.

\section{KESIMPULAN}

Transparansi di SKPD Kabupaten Bandung Barat sudah baik, karena telah menerapkan -prinsip prinsip transparansi yaitu adanya komunikasi publik oleh pemerintah dan hak masyarakat terhadap akses informasi

Akuntabilitas di SKPD Kabupaten Bandung Barat sudah baik, karena sudah memenuhi kriteria 4 (empat) dimensi yaitu akuntabilitas hukum dan kejujuran, akuntabilitas proses, akuntabilitas program, dan akuntabilitas kebijakan.

Kinerja Instansi Pemerintah di SKPD Kabupaten Bandung Barat sudah baik karena sudah memenuhi indikator-indikator kinerja instansi pemerintah yaitu adanya masukan (input), proses (process), keluaran (output), hasil (outcome), manfaat (benefit) dan dampak (impact)..

Transparansi berpengaruh terhadap kinerja instansi pemerintah pada SKPD Kabupaten Bandung Barat.

Akuntabilitas berpengaruh terhadap kinerja instansi pemerintah pada SKPD Kabupaten Bandung Barat. 
Transparansi dan akuntabilitas berpengaruh terhadap kinerja instansi pemerintah pada SKPD Kabupaten Bandung Barat. Hasil uji menunjukkan bahwa apabila akuntabilitas dan transparansi ditingkatkan pelaksanaanya maka akan meningkatkan kinerja pnstansi Pemerintah.

\section{REKOMENDASI}

Untuk Instansi Pemerintah perlu adanya mekanisme / pelayanan pengaduan jika terjadi pelanggaran atau permintaan untuk membayar uang suap. Perlu adanya pelayanan publik yang responsive. Perlu adanya aktivitas pencapaian suatu program dibandingkan dengan target kinerja

\section{DAFTAR PUSTAKA}

Arikunto, Suharsimi. (2013). Prosedur Penelitian. Jakarta: PT. Rineka Cipta

Auditya, L., Husaini \& Lismawati . (2013). Analisis Pengaruh Akuntabilitas Dan Transparansi Pengelolaan Keuangan Daerah Terhadap Kinerja PemerintahDaerah Provinsi Bengkulu (Vol. 3). Bengkulu: Fairness.

Badan Perencanaan Pembangunan Nasional, \& Departemen Dalam Negeri. (2002). Pedoman Penguatan Pengamanan Program Pembangunan Daerah.

Barker et al. (2002). Research Methods in Clinical Psychology. John Wiley \& Sons Ltd. England Bastian, Indra. (2006). Akuntansi Sektor Publik: Suatu Pengantar. Penerbit Erlangga:Jakarta.

Baswir, Revrisond. (2000). Koperasi Indonesia. Edisi Pertama. Yogyakarta: BPFE UGM.

Bharata, R. W. (2015). Pengaruh Akuntabilitas Dan Transparansi Terhadap Kinerja Pada Rumah Sakit Umum Daerah Wonosari (RSUD) Gunungkidul Daerah Istimewa Yogyakarta (Vol. 13). Ekonomi, Manajemen \& Akuntansi.
Dedi, Septian. Kinerja Pemerintahan KBB MEMPRIHATINKAN.

HYPERLINK

"HTTP://PASUNDANEKSPRES.COM/KINERJA-

PEMERINTAHAN-KBB-MEMPRIHATINKAN"

HTTP://PASUNDANEKSPRES.COM/KINERJA-

PEMERINTAHAN-KBB-MEMPRIHATINKAN

DiakSESTANGgaL 20 SePtember 2017.

Edison, Acep. (2016). Analisis Regresi dan Jalur dengan Program SPSS. Bandung: Mentari

Ellwood, Sheilla,1993, Parish Town and Councils; Financial Accountability and Management, Local Government Studies, Vol. 19,

Ghozali, I. (2013). Aplikasi Analisis Multivariate Dengan Program SPSS 21. Semarang: BP UNDIP.

Ibrahim, P. S. (2015). Pengaruh Anggaran Berbasis Kinerja,Transparansi, Akuntabilitas, Dan Pengawasan Internal Terhadap Kinerja Pegawai Sekretariat Jenderal DPR RI. Jurnal Tekun (Vol. 6).

Irianto, Agus. (2004). Statistik Konsep Dasar dan Aplikasinya. Jakarta: Kencana.

Keputusan Kepala Lembaga Administrasi Negara No. 589/IX/6/Y/99 tentang Pedoman Pelaporan Akuntabilitas Instansi Pemerintah

Krina, L. (2003). Indikator dan Alat Ukur Prinsip Akuntabilitas Transparansi dan Partisipasi. Jakarta: Sekretariat Good Public Governance, Badan Perencanaan Pembangunan Nasional.

LAN, \& BPKP. (2000). Akuntabilitas dan Good Governance Modul Sosialisasi Sistem AKIP (Vol. 1). Jakarta: LAN dan BPKP.

LAN, \& BPKP. (2003). Pedoman Penyusunan Pelaporan Akuntabilitas Kinerja Intansi.

LAN, \& BPKP. (2004). Modul Sistem Akuntabilitas Kinerja Instansi Pemerintah 
LUBIS, HeLdANIA UltRI. 10 RibuAN AdUAN WARGa KE OMBUDSMAN DI 2016, TERBANYAK SOAL PeMda. Dikutip tanggal 20 September 2017. HTTPS://NEWS.DETIK.COM/BERITA/D3417121/ 10-RIBUAN-ADUAN-WARGA-KE-OMBUDSMANDI-2016-TERBANYAK-SOAL-PEMDA.DIAKSES TANGgAL 13 SEPTEMBER 2017.

Lukito. (2014). Membumikan Transparansi dan Akuntabilitas Kinerja Sektor Publik:Tantangan Berdemokrasi Kedepan. Jakarta: PT Grasindo Anggota Ikapi.

Junaidi. (2010). Tabel $F$ dan Tabel $T$. (http://junaidichania go.wordpress.com).

Mangkunegara, A.A. Anwar Prabu. (2011). Manajmene Sumber Daya Manusia Perusahaan. Bandung: Rosda

Mardiasmo. (2009). Akuntansi Sektor Publik. Yogyakarta: ANDI.

Mardiasmo,2006, Perwujudan Transparansi dan Akuntabilitas Publik Melalui Akuntansi Sektor Publik : Suatu Sarana Good Governance, Jurnal Akuntansi Pemerintah, Vol.2, No.1, Mei

Noor, Juliansyah. (2011). Metodologi Penelitian: Skripsi, Tesis, Disertasi \& Karya Ilmiah. Jakarta: Kencana

Nordiawan, Deddi; Hertianti, Ayuningtyas. (2010). Akuntansi Sektor Publik. Jakarta: Salemba Empat

Peraturan Pemerintah No. 24 Tahun 2005 Tentang Sistem Akuntansi Pemerintah (SAP)

Peraturan Pemerintah Nomor 71 Tahun 2010 tentang Standar Akuntansi Pemerintah.

Peraturan Pemerintah Nomor 58 Tahun 2005 tentang Pengelolaan Keuangan Daerah.

Raco, J. R. (2010). Metode Penelitian Kualitatif Jenis, Karakteristik dan Keunggulannya. Jakarta: PT Grasindo.

Rakhmat, M.S., Prof. Dr. Drs. (2018). Administrasi dan Akuntabilitas Publik. Yogyakarta: ANDI
Riswan, Oris. evaluasi akuntabilitas, Kota BaNdUNG RaIH NILAI TERTINGgI. HTTPS://NEWS.OKEZONE.COM/READ/2016/02 /13/525/1311016/EVALUASI-AKUNTABILITAS KOTA-BANDUNG-RAIH-NILAI-TERTINGGI. DIAKSES TANGgAL 20 SEPTEMBER 2017.

ROCHMI, Muhammad Nur. KinerJa pemerintaH DAERAH MASIH RENDAH HYPERLINK "HTTPS://BERITAGAR.ID/ARTIKEL/BERITA/KINERJA -PEMERINTAH-DAERAH-MASIH-RENDAH" HTTPS://BERITAGAR.ID/ARTIKEL/BERITA/KINERJ A-PEMERINTAH-DAERAH-MASIH-RENDAH

DiaKSES TANGgal 15 SePTEMBer 2017.

Rosjidi. (2001). Akuntansi Sektor Publik Pemerintah:Kerangka, Standard dan Metode. Surabaya: Aksara Satu.

Saputra, Devi Satria; Darwanis; Abdullah, Syukriy. (2014). Pengaruh Transparansi, Akuntabilitas dan Komitmen Organisasi Terhadap Kinerja Satuan Kerja Perangkat Daerah (Studi Pada Pemda Kabupaten Aceh). Jurnal Akuntansi Program Pascasarjana Universitas Syiah Kuala Vol. 3 No. 2

Sari, Cecep Wijaya. Kall Kelima Kabupaten BANDUNG BARAT TERIMA OPINI WDP. HTTP://WWW.PIKIRANRAKYAT.COM/BANDUNGRAYA/2017/06/05/KALI-KELIMA-KABUPATEN BANDUNG-BARAT-TERIMA-OPINI-WDP-402547. DiaKSES TANGgaL 19 SEPTEMBER 2017.

Sudjana. (2005). Metode Statistika. Bandung: Tartinto.

Sugiyono. (2014). Metode Penelitian Kuantitatif Kualitatif dan R\&D. Bandung:Alfabeta.

Sukmaningrum, Puji harto, 2009. Analisis FaktorFaktor yang Mempengaruhi Kualitas Laporan Keuangan Pemerintah Daerah (Studi Empiris pada Pemerintah Kabupaten dan Kota Semarang), Jurnal Akuntansi. 
Sulistiyani, Ambar Teguh: Rosidah. (2003). Manajemen Sumber Daya Manusia. Yogyakarta: Graha IImu.

Tuasikal , A, 2007, Pengaruh sistem Akuntansi, Pengelolaan Keuangan Daerah Terhadap Kinerja Satuan Kerja Pemerintah Daerah (Studi pada Kapupaten Maluku Tengah di Provinsi Maluku), Jurnal Akuntansi Dan Keuangan Sektor Publik, Vol. 08, No.01

Undang-Undang No. 22 Tahun 1999 tentang Pemerintahan Daerah

Undang-Undang No. 23 Tahun 2014 tentang Pemerintahan Daerah

Widodo, J. (2011). Analisis Kebijakan Publik (Konsep dan Aplikasi Proses Kebijakan Publik). Malang: Bayumedia.

Wiguna, M. B., Yuniartha, G. A., \& Darmawan, N. A. (2015). Pengaruh Pengawasan Keuangan Daerah, Akuntabilitas Dan Transparansi Pengelolaan Keuangan Daerah Terhadap Kinerja Pemerintah Daerah Kabupaten Buleleng (Vol. 3). eJournal S1 Ak Universitas Pendidikan Ganesha .

Zulganef. (2008). Metode Penelitian Sosial dan Bisnis. Bandung: Graha Ilmu.

\footnotetext{
(2016).Kota Bandung Menuju PEMERINTAHAN YANG TERBUKa. HTTP://WWW.PIKIRAN-

RAKYAT.COM/BANDUNGRAYA/2016/11/25/KOTA-BANDUNG-MENUJUPEMERINTAHAN-YANG-TERBUKA-385853.

DiakSES TANGgal 17 SePtember 2017.
} 